\title{
Use of probiotic-supplemented diet on a Pacific white shrimp farm
}

\section{Felipe do Nascimento Vieira1, Adolfo Jatobá², José Luiz Pedreira Mouriño1, Celso Carlos Buglione Neto ${ }^{3}$, Jairo Sousa da Silva ${ }^{4}$, Walter Quadros Seiffert ${ }^{1}$, Mariana Soares ${ }^{1}$, Luis Alejandro Vinatea ${ }^{1}$}

\author{
${ }^{1}$ Universidade Federal de Santa Catarina, Centro de Ciências Agrárias, Departamento de Aquicultura, Florianópolis, SC, Brazil. \\ ${ }^{2}$ Instituto Federal Catarinense, Araquari, SC, Brazil. \\ ${ }^{3}$ Itaipu, Foz do Iguaçu, SC, Brazil. \\ ${ }^{4}$ Universidade Federal de Santa Catarina, Departamento de Aquicultura, Fazenda Experimental Yakult, Balneário Barra do Sul, SC, Brazil.
}

\begin{abstract}
The objective of this study was to evaluate the use of a diet supplemented with Lactobacillus plantarum on performance, immunological parameters, and bacterial microbiota of the digestive tract of white leg shrimp (Litopenaeus vannamei). We used six earthen ponds (1.2 ha) stocked with 14 shrimp $\mathrm{m}^{-2}$ ( $3 \mathrm{~g}$ mean weight). Three ponds received a diet supplemented with L. plantarum and three were maintained as control. The survival and feed efficiency of shrimp fed the supplemented diet were greater than that observed in shrimp fed the control diet, with survival values of $83.02 \pm 6.12 \%$ and $74.65 \pm 9.07 \%$ and feed efficiencies of $117.97 \pm 4.45 \%$ and $104.46 \pm 7.30 \%$, respectively. However, we observed no differences in weight gain. The intestines of shrimp fed probiotics had lower counts of Vibrio spp. and higher counts of lactic acid bacteria, compared with those of control shrimp. Diets supplemented with L. plantarum alter the intestinal bacterial microbiota of shrimp, resulting in increased survival and feed efficiency.
\end{abstract}

Key Words: immune response, Lactobacillus, microbiology

\section{Introduction}

Recently, the interest in the use of probiotics in aquaculture to prevent diseases and increase resistance to pathogens has increased (Akhter et al., 2015). Gatesoupe (1999) defined a probiotic as "microbial cells that are administered in such a way as to be kept alive, with the aim of improving health". The use of probiotics produces benefits for marine shrimp by improving the balance of the intestinal microbiota (Vieira et al., 2008), survival (Pham et al., 2014), resistance to infection by pathogens (AguileraRivera et al., 2014), immune stimulation (Ferreira et al., 2015), and diet digestibility (Buglione Neto, 2009). Unlike antibiotics, this method does not leave any residues in the shrimp meat (Kesarcodi-Watson et al., 2008).

Lactic acid bacteria are among one of the most used probiotics in aquaculture, due to their rapid reproduction, production of antimicrobial compounds (organic acids, lactic acid, bacteriocins, and hydrogen peroxide), and stimulation of non-specific immune responses in their hosts

Received October 17, 2015 and accepted March 4, 2016.

Corresponding author: felipe.vieira@ufsc.br

http://dx.doi.org/10.1590/S1806-92902016000500001

Copyright (C) 2016 Sociedade Brasileira de Zootecnia. This is an Open Access article distributed under the terms of the Creative Commons Attribution License (http://creativecommons.org/licenses/by/4.0/), which permits unrestricted use, distribution, and reproduction in any medium, provided the original work is properly cited.
(Pandiyan et al., 2013). However, most studies on probiotics and marine crustaceans have been performed on a small laboratory scale and under controlled laboratory conditions (Vieira et al., 2007, 2008, 2010; Pham et al., 2014; Ferreira et al., 2015). Because laboratory conditions do not always match the conditions on commercial farms, there is a need for studies on the use of probiotics on commercial farms.

The objective of this study was to evaluate the use of a diet supplemented with Lactobacillus plantarum on performance, immunological parameters, and bacterial microbiota of the digestive tract of white leg shrimp (Litopenaeus vannamei) on a farm in the State of Santa Catarina, Brazil.

\section{Material and Methods}

The experiment was conducted in Balneário Barra do Sul, Santa Catarina, Brazil $\left(26^{\circ} 32^{\prime} \mathrm{S}\right.$ and $\left.48^{\circ} 39^{\prime} \mathrm{W}\right)$, from February to April 2008.

We used the probiotic strain $L$. plantarum (accession \#CPQBA 00707 DRM01), which was isolated from an adult shrimp (L. vannamei) (Vieira et al., 2007).

Lactobacillus plantarum was grown in MRS liquid culture medium (Difco ${ }^{\circledR}$; de Man, Rogosa and Sharpe, 1960) for $24 \mathrm{~h}$ under continuous agitation to a concentration of $10^{9} \mathrm{cfu} \mathrm{mL}^{-1}$. The probiotic was added to commercial rations (Table 1) at a ratio of $100 \mathrm{~mL} \mathrm{~kg}^{-1}, 30 \mathrm{~min}$ before being provided to the shrimp. 
Twenty-day-old shrimp post-larvae (PL20) were cultured in an intensive nursery ( 100 shrimp $\left.\mathrm{m}^{-2}\right)$ until they reached a mean weight of $3 \mathrm{~g}$. They were then transferred to six ponds of 1.20 ha at a mean stocking density of 14 shrimp $\mathrm{m}^{-2}$. A randomised complete block design was used, with three blocks of two ponds stocked with shrimp from the beginning, middle, and end of the nursery tank harvest. Shrimp in one pond from each block were fed commercial diets supplemented with $L$. plantarum, and the shrimp in the other pond were fed control diets. The diets ( $32 \%$ protein) were provided twice daily $(9.00 \mathrm{~h}$ and $16.00 \mathrm{~h}$ ) in trays at approximately $3 \%$ of the biomass quantity.

The water temperature was measured daily (at $0.00 \mathrm{~h}$, $5.00 \mathrm{~h}$, and $17.00 \mathrm{~h}$ ), as well as dissolved oxygen levels at the surface and bottom, using an oximeter (Alfakit ${ }^{\circledR}$ AT-150) and the concentrations of ammonia, nitrate, nitrite, and orthophosphate (according to Grasshoff et al., 1983) and pH (Alfakit ${ }^{\circledR}$ AT-300).

To evaluate weight gain, 30 shrimp from three points in the pond were collected every 15 days. The survival rates and feed efficiencies at the end of the culture period were evaluated. Thirty and sixty days after stocking, 20 shrimp (two pools of 10 animals) were collected per tank to evaluate immunological parameters (total haemocyte count, phenoloxidase enzyme activity, and the antimicrobial activity of the serum), the presence of bacteria in the haemolymph and hepatopancreas, as well as the bacterial microbiota of the digestive tract. Furthermore, the pleopods from 150 shrimp per pond were collected to detect white spot syndrome virus (WSSV) and the water sample from each pond was evaluated for its environmental bacterial microbiota.

The water samples were 1:10 serially diluted five times and plated on marine agar ( Difco $^{\circledR}$ ), Thiosulfate Citrate Bile Sucrose Agar (TCBS, Difco ${ }^{\circledR}$ ), and MRS agar for counts

Table 1 - Composition of the commercial feed

\begin{tabular}{lc}
\hline Ingredient & Final percentage (\%) \\
\hline Soybean meal & 19.40 \\
Fishmeal & 21.00 \\
$43 \%$ meat & 8.80 \\
Wheat bran & 10.00 \\
33\% sugarcane dry yeast & 10.00 \\
Rice bran (solvent extracted) & 5.00 \\
Liquid molasses & 4.00 \\
Broken rice & 8.30 \\
Hydrolysed feather meal & 4.00 \\
Fish oil & 1.50 \\
Tuna flavouring & 4.00 \\
Mono-dicalcium phosphate & 1.35 \\
Refined salt & 0.50 \\
Mineral-vitamin premix & 2.15 \\
Total & 100.00 \\
\hline
\end{tabular}

of total bacteria, vibrionaceae, and lactic acid bacteria, respectively. Colony-forming units (cfu) were counted after a 24-h incubation period for marine agar and TCBS agar plates and after $48 \mathrm{~h}$ for MRS agar plates.

From the ventral sinus of each shrimp, $300 \mu \mathrm{L}$ haemolymph were collected using sterile $1-\mathrm{mL}$ syringes with $21-\mathrm{G}$ needles, previously cooled at $4{ }^{\circ} \mathrm{C}$ to prevent coagulation. One 10- $\mu \mathrm{L}$ sample of the collected haemolymph was fixed in modified Alsever's solution ( $27 \mathrm{mM}$ sodium citrate, $336 \mathrm{mM} \mathrm{NaCl}, 115 \mathrm{mM}$ glucose, $9 \mathrm{mM}$ EDTA, $\mathrm{pH}$ 7.0) supplemented with $4 \%$ of formalin for the total haemocyte count (THC). The other $10-\mu \mathrm{L}$ aliquots of haemolymph were used for microbiological evaluations, and the rest of the sample was left at $4{ }^{\circ} \mathrm{C}$ to coagulate. The clot was congealed $\left(-20^{\circ} \mathrm{C}\right)$ and defrosted $(3 \times)$ to allow for cellular rupture and the release of the granular content, and was then repeatedly centrifuged at $4{ }^{\circ} \mathrm{C}(2,000 \times g$ for 10 min). The supernatant or serum was aliquoted and stored at $-20{ }^{\circ} \mathrm{C}$ for subsequent analyses.

After haemolymph collection, a hepatopancreas sample was carefully removed to avoid digestive tract rupture and, consequently, contaminating the sample $(n=60$ per treatment). Finally, the intestines of the shrimp were excised and weighed in pools of five animals.

A sample of the collected haemolymph $(10 \mu \mathrm{L})$ was plated on Petri dishes with TCBS agar under sterile conditions. The hepatopancreas samples were macerated in SSE and plated on TCBS agar Petri dishes under sterile conditions. The plates were incubated at $30{ }^{\circ} \mathrm{C}$ for $24 \mathrm{~h}$ to detect the presence of Vibrio spp.

The digestive tract samples were macerated in sterile saline solution at a 1:1 ratio (w:v). The samples were then 1:10 serially diluted five times in saline and plated onto Petri dishes with marine agar, TCBS agar, and MRS agar $\left(\right.$ Difco $\left.^{\circledR}\right)$. The cfu were counted after a 24-h incubation period for the marine agar and TCBS agar and after $48 \mathrm{~h}$ for the MRS agar. The colonies that grew on MRS agar were Gram-stained to confirm that their morphology was similar to that of the original probiotic.

The THC was estimated using a Neubauer chamber, and the serum total protein concentration was estimated via a Bradford (1976) assay, using bovine serum albumen $(22 \%)$ as a standard.

Phenoloxidase enzymatic activity was determined by a colorimetric method by the formation of the pigment DOPA-chrome, after the enzymatic oxidation of the substrate L-dihydroxyphenylalanine (L-DOPA, Sigma), according to Söderhäll and Häll (1984).

For antimicrobial analysis, the bacterial strains Vibrio harveyi ATCC 14126 (pathogenic to the marine shrimp), 
Escherichia coli D363 (a Gram-negative standard), and Staphylococcus aureus A270 (a Gram-positive standard) were used. Vibrio alginolyticus was cultured in saline peptone water (SPW) (1.5\% peptone, $1.5 \% \mathrm{NaCl}, \mathrm{pH} 7.2)$, whereas the other bacteria were cultured in Luria Bertani ( $1 \%$ peptone, $0.5 \%$ yeast extract, $0.5 \% \mathrm{NaCl}, \mathrm{pH} 7.2$ ) for $24 \mathrm{~h}$ at $30{ }^{\circ} \mathrm{C}$. The assays were performed by serially diluting $50 \mu \mathrm{L}$ serum in SPW for $V$. harveyi or poor broth (PB) (1\% peptone, $0.5 \% \mathrm{NaCl}, \mathrm{pH} 7.4)$ for the other bacteria in 96 well, flat bottomed microtiter plates. Each

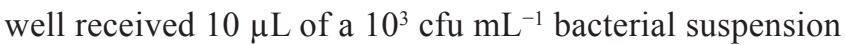
in the log phase. For the controls, the serum was substituted by saline. Bacterial growth was determined in a microplate reader $\left(\mathrm{OD}_{630}\right)$. The antimicrobial activity was estimated to be the reciprocal of the last well that inhibited bacterial growth.

The presence of WSSV was determined by nested PCR, using the primers and conditions described by Lo et al. (1996).

The total haemocyte counts and bacterial counts were transformed by $\log (\mathrm{x}+1)$ for standardization and homogeneity of variances. The antimicrobial activity values were transformed by $\log _{2}(\mathrm{x})$. We used ANOVA with a randomized complete block design $(\alpha=0.05)$ for the animal performance indices, and we used ANOVA with a randomized complete block design and repeated measures $(\alpha=0.05)$ for the remaining analyses (Zar, 1984).

\section{Results and Discussion}

The bottom temperature $\left(23.2-30.2{ }^{\circ} \mathrm{C}\right)$, surface temperature $\left(24.5-31.3{ }^{\circ} \mathrm{C}\right)$, bottom dissolved oxygen (2.5-6.7 $\left.\mathrm{mg} \mathrm{L}^{-1}\right)$, surface oxygen (3.1-8.9 $\left.\mathrm{mg} \mathrm{L}^{-1}\right)$, $\mathrm{pH}(7.8$ 8.6), ammonia (0.018-0.023 $\left.\mathrm{mg} \mathrm{L}^{-1}\right)$, nitrite $\left(0-0.01 \mathrm{mg} \mathrm{L}^{-1}\right)$, nitrate $\left(0.66-0.89 \mathrm{mg} \mathrm{L}^{-1}\right)$, and orthophosphate $(0.007$ $0.019 \mathrm{mg} \mathrm{L}^{-1}$ ) remained within the recommended limits for culturing L. vannamei.

The total bacterial counts $\left(1.51 \pm 0.74 \times 10^{4} \mathrm{cfu} \mathrm{mL}^{-1}\right)$ and Vibrio spp. counts $\left(1.22 \pm 0.52 \times 10^{2} \mathrm{cfu} \mathrm{mL}^{-1}\right)$ in the culture water did not vary between treatments or collection periods ( $\mathrm{P} \geq 0.05)$ and were similar to the values observed by Sung et al. (2001) on a P. monodom farm. As expected, we did not observe the presence of lactic acid bacteria in the culture water. Lactic acid bacteria are normally associated with the microbiota of the digestive tract of animals (Kongnun and Hongpattarakere, 2012); thus, they should not interfere with bacterial populations in the water column.

Lactic acid bacteria counts in the digestive tract of shrimp fed diets supplemented with $L$. plantarum were higher $(\mathrm{P}<0.05)$ than those in the control shrimp, for both collection periods. There were also fewer Vibrio spp. $(\mathrm{P}<0.05)$ in the digestive tract of shrimp fed the supplemented diets compared with the controls. There was no difference $(\mathrm{P} \geq 0.05)$ in total bacterial counts from the digestive tract of the treated and control shrimp, for both collection periods (Table 2).

As observed by Vieira et al. (2008) in laboratory conditions, the present study demonstrated that the diets supplemented with $L$. plantarum also altered the microbiota of shrimp on farm. The presence of lactic acid bacteria in the intestinal tract can enhance the animal immune system, resulting in shrimp more resistant to disease in the cultivation environment.

The alteration of the bacterial microbiota in the intestinal tract of marine shrimp by dietary probiotics is an important preventive tool against disease (Kongnun and Hongpattarakere, 2012). A significant reduction in the abundance of Vibrio spp. was found in the intestinal tract of shrimp fed the probiotic-supplemented diet, followed by an increase in the abundance of lactic acid bacteria (Table 2). This result is related to the ability of lactic acid bacteria such as L. plantarum to inhibit the adhesion of pathogenic bacteria to the intestinal mucosa (Balcázar et al., 2008) and to produce antimicrobial substances such as plantaricin (Hernández et al., 2005), hydrogen peroxide, and organic acids (Kongnun and Hongpattarakere, 2012). Therefore, the use of L. plantarum in the diet can help in the prevention of Vibrio disease, such as the acute hepatopancreatic necrosis disease (AHPND), which is

Table 2 - Bacterial microbiota in the digestive tract of shrimp (Litopenaeus vannamei) fed a control diet or a diet supplemented with L. plantarum, after 30 and 60 days of cultivation

\begin{tabular}{lcccc}
\hline \multirow{2}{*}{ Collection } & Treatment & \multicolumn{3}{c}{ Microbiological evaluation of the digestive tract $\left(\mathrm{cfu} \mathrm{g}^{-1}\right)$} \\
\cline { 3 - 5 } 30 days & & Total bacteria & Total Vibrio spp. & Total lactic acid \\
& Probiotic & $1.56 \pm 0.21 \times 10^{7}$ & $4.98 \pm 0.08 \times 10^{4 *}$ & $5.64 \pm 1.50 \times 10^{4 *}$ \\
\multirow{2}{*}{60 days } & Control & $2.36 \pm 0.28 \times 10^{7}$ & $1.10 \pm 0.48 \times 10^{5}$ & $1.67 \pm 0.24 \times 10^{1}$ \\
& Probiotic & $2.75 \pm 1.51 \times 10^{5}$ & $1.33 \pm 0.81 \times 10^{3 *}$ & $2.15 \pm 1.02 \times 10^{4 *}$ \\
\hline
\end{tabular}

*Significantly different in the analysis of variance $(\mathrm{P}<0.05)$. 
Table 3 - Survival, feed efficiency, days of cultivation, final weight, and productivity in shrimp (Litopenaues vannamei) fed diets supplemented (probiotic) or not supplemented (control) with L. plantarum

\begin{tabular}{lccccc}
\hline Treatment & Survival $(\%)$ & Feed efficiency $(\%)$ & Days of cultivation & Final weight (g) & \left.${\text { Productivity }\left(\mathrm{kg}^{-1}\right)}^{-1}\right)$ \\
\hline Probiotic & $83.02 \pm 6.12^{*}$ & $117.97 \pm 4.45^{*}$ & $77.00 \pm 6.42$ & $11.2 \pm 0.62$ & $1325.61 \pm 74.44$ \\
Control & $74.65 \pm 9.07$ & $104.46 \pm 7.30$ & $72.33 \pm 9.7$ & $11.96 \pm 0.35$ & $1291.13 \pm 192.92$ \\
\hline
\end{tabular}

*Significant difference for the analysis of variance $(\mathrm{P}<0.05)$

Table 4 - Phenoloxidase enzyme activity (PO), total haemocyte count (THC), and antimicrobial activity against Vibrio alginolyticus, Staphylococcus aureus, and Escherichia coli of the haemolymph from shrimp (Litopenaeus vannamei) fed a diet supplemented with L. plantarum or control diet after 30 and 60 days of cultivation

\begin{tabular}{|c|c|c|c|c|c|c|}
\hline \multirow{2}{*}{ Collection } & \multirow{2}{*}{ Treatment } & \multicolumn{2}{|c|}{ Immunological parameter } & \multicolumn{3}{|c|}{ Minimum inhibitory concentration $\left(\mathrm{mg}\right.$ of protein $\left.\mathrm{mL}^{-1}\right)$} \\
\hline & & PO $\left(\mathrm{U} \mathrm{min}^{-1} \mathrm{mg}^{-1}\right)$ & $\mathrm{THC}\left(\times 10^{6} \mathrm{~mL}^{-1}\right)$ & V. alginolyticus & S. aureus & E. coli \\
\hline \multirow[t]{2}{*}{30 days } & Probiotic & $71.37 \pm 9.93$ & $36.26 \pm 8.58$ & $8.44 \pm 1.81$ & $9.05 \pm 0.18$ & $10.84 \pm 1.22$ \\
\hline & Control & $80.95 \pm 3.92$ & $35.60 \pm 11.77$ & $15.38 \pm 7.55$ & $8.02 \pm 1.69$ & $13.31 \pm 0.98$ \\
\hline \multirow[t]{2}{*}{60 days } & Probiotic & $82.46 \pm 4.67$ & $41.67 \pm 28.66$ & $2.66 \pm 2.66$ & $8.71 \pm 1.30$ & $13.89 \pm 5.66$ \\
\hline & Control & $78.16 \pm 13.30$ & $40.93 \pm 13.53$ & $4.66 \pm 2.40$ & $11.02 \pm 3.94$ & $10.66 \pm 2.59$ \\
\hline
\end{tabular}

dramatically affecting the culture of shrimp in Asia and Mexico (Nunan et al., 2013).

The survival of shrimp supplemented with $L$. plantarum was higher $(\mathrm{P}<0.05)$ (Table 3). Bacteria of the genus Vibrio are known pathogens of marine shrimp (Vanmaele et al., 2015). Thus, the increased survival of shrimp supplemented with $L$. plantarum might be related to the decreased abundance of Vibrio spp. in the digestive tract. In L. stylirostris, diets supplemented with Pediococcus acidilactici also resulted in increased survival and reduced the populations of Vibrio spp. in the digestive tract, under similar field conditions (Castex et al., 2008). Wang et al. (2007) reported an increase in the survival of $L$. vannamei in commercial culture tanks using a commercial probiotic Bacillus sp.

Feed efficiency was higher $(\mathrm{P}<0.05)$ in shrimp fed supplemented diets (Table 3 ). Probiotic bacteria can produce or stimulate the production of digestive enzymes in the host (Kongnun and Hongpattarakere, 2012). Buglione Neto (2009) demonstrated an enhanced apparent digestibility of crude protein in $L$. vannamei supplemented with $L$. plantarum in commercial diets, which might explain the improved feed efficiency we observed here. Similar improvements in feed efficiency have been reported by Wang (2007) in the commercial culture of L. vannamei in China using commercial probiotics. However, there was no significant difference among the treatments in the final weight of shrimp, productivity or the number of days of culture ( $\mathrm{P} \geq 0.05)$ (Table 3 ).

Lactic acid bacteria in the intestinal tract can also produce immunostimulatory substances (Gill, 2003). In L. vannamei, the use of a diet supplemented with
L. plantarum stimulated an immunological response as reported by Vieira et al. $(2008,2010)$. However, we observed no differences in immunological parameters between treatments $(\mathrm{P} \geq 0.05)$ (Table 4).

In studies by Vieira et al. (2008), the immunological parameters of shrimp supplemented with L. plantarum changed in relation to control shrimp only after experimental infection with $V$. harveyi. In the present study, neither Vibrio spp. (haemolymph and hepatopancreas) nor WSSV was detected in the shrimp. Thus, the shrimp we sampled were healthy, which might explain why no changes were observed in the immunological parameters evaluated.

\section{Conclusions}

The use of a diet supplemented with $L$. plantarum increases the survival and feed efficiency of shrimp raised on farm.

Diets supplemented with $L$. plantarum modify the intestinal bacterial microbiota of shrimp raised on a commercial farm, decreasing the abundance of Vibrio spp. and increasing the abundance of lactic acid bacteria.

\section{Acknowledgments}

The authors are especially thankful to Professor Elpídio Beltrame (in memoriam) from the Department of Aquaculture at UFSC, for his inestimable support in this study. Felipe Vieira, Walter Seiffert, José Mouriño, and Luis Vinatea receive 'productivity research' fellowships from CNPq (cases no. PQ 302792/2012-0, 309868/2014-9, $308292 / 2014-6,302051 / 2011-2$, respectively). The authors 
also thank Ministério da Pesca e Aquicultura (MPA), Financiadora de Estudos e Projetos (FINEP), and Fundação de Apoio à Pesquisa Científica e Tecnológica do Estado de Santa Catarina (FAPESC) for financial support.

\section{References}

Aguilera-Rivera, D.; Prieto-Davó, A.; Escalante, K.; Chávez, C.; Cuzon, G. and Gaxiola, G. 2014. Probiotic effect of FLOC on Vibrios in the pacific white shrimp Litopenaeus vannamei. Aquaculture 424-425:215-219. doi: 10.1016/j.aquaculture.2014.01.008.

Akhter, N.; Bin, B.; Memon, A. M. and Mohsin, M. 2015. Probiotics and prebiotics associated with aquaculture: A review. Fish \& Shellfish Immunology 45:733-741. doi: 10.1016/j.fsi.2015.05.038.

Balcazar, J. L.; Vendrell, D.; De Blas, I.; Ruiz-Zarzuela, I.; Muzquiz, J. L. and Girones, O. 2008. Characterization of probiotic properties of lactic acid bacteria isolated from intestinal microbiota of fish. Aquaculture 278:188-191. doi: 10.1016/j.aquaculture.2008.03.014.

Bradford, M. M. 1976. Rapid and sensitive method for quantitation of microgram quantities of protein utilizing principle of protein-dye binding. Analytical Biochemistry 72:248-254.

Buglione Neto, C. C. 2009. Avaliação do coeficiente de digestibilidade aparente da proteína, energia e matéria seca em ração comercial suplementada com probiótico para Litopennaeus vannamei. Dissertação (M.Sc.). Universidade Federal de Santa Catarina, Florianópolis.

Castex, M.; Chim, L.; Pham, D.; Lemaire, P.; Wabete, N.; Nicolas, J. L.; Schmidely, P. and Mariojouls, C. 2008. Probiotic P-acidilactici application in shrimp Litopenaeus stylirostris culture subject to vibriosis in New Caledonia. Aquaculture 275:182-193. doi: 10.1016/j.aquaculture.2008.01.011.

Ferreira, G. S.; Bolívar, N. C.; Pereira, S. A.; Guertler, C.; Vieira, F. V.; Mouriño, J. L. P. and Seiffert, W. Q. 2015. Microbial biofloc as source of probiotic bacteria for the culture of Litopenaeus vannamei. Aquaculture 448:273-279. doi: 10.1016/j.aquaculture.2015.06.006.

Gatesoupe, F. J. 1999. The use of probiotics in aquaculture. Aquaculture 180:147-165. doi: 10.1016/S0044-8486(99)00187-8.

Gill, H. S. 2003. Probiotics to enhance anti-infective defences in the gastrointestinal tract. Best Practice \& Research in Clinical Gastroenterology 17:755-773. doi: 10.1016/S1521-6918(03)00074-X.

Grasshoff, K. M.; Ehrhardt, K. and Kremling, K. 1983. Methods of seawater analysis. Verlag Chemie, Basel. doi: 10.1002/ 9783527613984.

Hernandez, D.; Cardell, E. and Zarate, V. 2005. Antimicrobial activity of lactic acid bacteria isolated from Tenerife cheese: initial characterization of plantaricin TF711, a bacteriocin-like substance produced by Lactobacillus plantarum TF711. Journal of Applied Microbiology 99:77-84. doi: 10.1111/j.1365-2672.2005.02576.x.

Kesarcodi-Watson, A.; Kaspar, H.; Lategan, M. J. and Gibson, L. 2008. Probiotics in aquaculture: The need, principles and mechanisms of action and screening processes. Aquaculture 274:1-14. doi:10.1016/j.aquaculture.2007.11.019.

Kongnum, K. and Hongpattarakere, T. 2012. Effect of Lactobacillus plantarum isolated from digestive tract of wild shrimp on growth and survival of white shrimp (Litopenaeus vannamei) challenged with Vibrio harveyi. Fish \& Shellfish Immunology 32:170-177. doi: 10.1016/j.fsi.2011.11.008.

Lo, C. F.; Leu, J. H.; Ho, C. H.; Chen, C. H.; Peng, S. E.; Chen, Y. T.; Chou, C. M.; Yeh, P. Y.; Huang, C. J.; Chou, H. Y.; Wang, C. H. and Kou, G. H. 1996. Detection of baculovirus associated with white spot syndrome (WSBV) in penaeid shrimps using polymerase chain reaction. Diseases of Aquatic Organisms 25:133-141.

Nunan, L.; Lightner, D.; Pantoja, C. and Gomez-Jimenez, S. 2013. Detection of acute hepatopancreatic necrosis disease (AHPND) in Mexico. Diseases of Aquatic Organisms 111:81-86.

Pandiyan, P.; Balaraman, D.; Thirunavukkarasu, R.; George, E. G. J.; Subaramaniyan, K.; Manikkam, S. and Sadayappan, B. 2013. Probiotics in aquaculture. Drug Invention Today 5:55-59. doi: 10.1016/j.dit.2013.03.003.

Pham, D.; Ansquer, D.; Chevalier, A.; Dauga, C.; Peyramale, A.; Wabete, N. and Labreuche, Y. 2014. Selection and characterization of potential probiotic bacteria for Litopenaeus stylirostris shrimp hatcheries in New Caledonia. Aquaculture 432:475-482. doi: 10.1016//j.aquaculture.2014.04.031.

Soderhall, K. and Hall, L. 1984. Lipopolysaccharide-Induced activation of prophenoloxidase activating system in crayfish hemocyte lysate. Biochimica et Biophysica Acta 797:99-104. doi: 10.1016/0304-4165(84)90387-8.

Sung, H. H.; Hsu, S. F.; Chen, C. K.; Ting, Y. Y. and Chao, W. L. 2001. Relationships between disease outbreak in cultured tiger shrimp (Penaeus monodon) and the composition of Vibrio communities in pond water and shrimp hepatopancreas during cultivation. Aquaculture 192:101-110. doi: 10.1016/S0044-8486(00)00458-0.

Vanmaele, S.; Defoirdt, T.; Cleenwerck, I. and Bossier, P. 2015. Characterization of the virulence of Harveyi clade vibrios isolated from a shrimp hatchery in vitro and in vivo, in a brine shrimp (Artemia franciscana) model system. Aquaculture 435:28-32. doi: 10.1016/j.aquaculture.2014.09.015.

Vieira, F. D.; Pedrotti, F. S.; Buglione Neto, C. C.; Mourino, J. L. P.; Beltrame, E.; Martins, M. L.; Ramirez, C. and Arana, L. A. V. 2007. Lactic-acid bacteria increase the survival of marine shrimp, Litopenaeus vannamei, after infection with Vibrio harveyi. Brazilian Journal of Oceanography 55:251-255. doi: 10.1590/ S1679-87592007000400002.

Vieira, F. D.; Buglione Neto, C. C.; Mourino, J. L. P.; Jatobá, A.; Ramirez, C.; Martins, M. L.; Barracco, M. A. A. M. and Vinatea, L. A. 2008. Time-related action of Lactobacillus plantarum in the bacterial microbiota of shrimp digestive tract and its action as immunostimulant. Pesquisa Agropecuária Brasileira 43:763-769. doi: 10.1590/S0100-204X2008000600013.

Vieira, F. N.; Buglione, C. C.; Mourino, J. P. L.; Jatobá, A.; Martins, M. L.; Schleder, D. D.; Andreatta, E. R.; Barraco, M. A. and Vinatea, L. A. 2010. Effect of probiotic supplemented diet on marine shrimp survival after challenge with Vibrio harveyi. Arquivo Brasileiro de Medicina Veterinária e Zootecnia 62:631-638. doi: 10.1590/S010209352010000300019.

Wang, Y. B. 2007. Effect of probiotics on growth performance and digestive enzyme activity of the shirmp Penaeus vannamei. Aquaculture 269:259-264. doi: 10.1016/j.aquaculture.2007.05.035.

Zar, J. H. 1984. Biostatistical analysis. Prentice Hall, Englewood Cliffs, NJ. 